\title{
VAPAAN SIVISTYSTYÖN ELÄVÄ YDIN
}

\begin{abstract}
Vapaa sivistystyö on halki olemassaolonsa käynyt vuoropuhelua kunkin aikakauden henkisten virtausten kanssa. Sen toiminnat ovat laajentuneet ja muuttuneet ajan tarpeiden mukaan ja ne ovat aina palvelleet kunkin aikakauden kansalaisyhteiskuntaa, sen tarpeita. Ellei näin olisi tapahtunut, vapaa sivistystyö olisi kuollut. Sen tarjoamat palvelut ovat aina olleet ihmisten vapaasti otettavissa tai jätettävissä. Vapaan sivistystyön tulevaisuuden kannalta tämä merkitsee sitä, että sen alkuperäisen idean mukainen historian ja kulttuurin merkitystä sivistystyölle korostava tietokäsitys ja siihen pohjaava pedagogiikka ovat yhä päteviä työvälineitä. Sivistystyön tehtävä on yhäkin auttaa ihmisiä jäsentämään oma asemansa sen kulttuurin piirissä, jossa he elävät.
\end{abstract}

Vapaalla sivistystyöllä ymmärretään Suomessa kansan-, kansalais- ja työväenopisto- sekä sivistysjärjestöjen opintokeskustoimintaa. Toiminnalla on yli 100-vuotinen historia ja tänään ollaan tilanteessa, jossa tämän työn merkitykseen ja toiminta-ajatukseen kohdistetaan sama kriittinen kysymys kuin muuhunkin koulutukseen. Kysytään, onko vapaalla sivistystyöllä jokin erityinen tehtävä ja onko sillä annettavaa koulutuksen tulevaisuudelle. Tarkoitukseni on seuraavassa pohtia tätä ongelmaa kysymällä, onko vapaan sivistystyön toimintaa historiassa ohjanneella sivistyskäsityksellä merkitystä yhä tänä päivänä.

Vapaa kansansivistystyö on pohjoismainen kansanliike, Pohjolan lahja sivistyneelle maailmalle. Sen synty ajoittuu 1800-luvun puolivälin Tanskaan, mistä se 1900-luvun alkuun tultaessa oli laajentunut kaikkialle pohjoismaihin.

N. F. S. Grundtvig (1783 - 1872) on liikkeen suuri perustanlaskija. Hän oli tanskalais-kansallinen herättäjä, pappi, kirjailija ja poliitikko. Hän ei itse juurikaan ollut käytännön pedagogi, mutta hänen sivistyskäsityksensä ja kasvatusta koskeva ajattelunsa muodostuivat konkreettiseksi perustaksi työlle, jota toiset alkoivat toteuttaa.

\section{Alussa oli Grundtvig}

Grundtvigin laaja ja monipolvinen sivistyksen olemusta ja käytännöllisen kasvatustyön ehtoja koskeva ajattelu on tämän artikkelin tavoitteiden kannalta pelkistettävissä kahteen keskeiseen näkemykseen. Grundtvig katsoi, että (1) sivistyksen käsite, sen mahdollisuus, on ymmärrettävä sisällöltään historiallisesti määräytyväksi ja, että (2) käytännön kasvatustyön on aina lähdettävä kasvatettavan henkilökohtaisista tarpeista ja sen on perustuttava opettajan sekä oppilaan elävään persoonalliseen vuorovaikutukseen ja molemminpuoliseen kunnioitukseen. Näiden ajatusten taustalla ovat valistuksen ihmisusko ja romantiikan sekä nationalismin historiakuva.

Grundtvigille itselleen sivistyksen historiallisesti määräytyvä sisältö merkitsi universaalin sivistyksen idean kritiikkiä. Hänen omaksumansa romantiikan ja nationalismin maailmankatsomuksen mukaisesti kaiken aitoon sivistykseen pyrkivän kasvatuksen ja opetuksen tuli perustua kasvatettavan omaan kieleen ja kulttuuriin. Meidän kielellämme ilmaistuna Grundtvigin ajatus merkitsee, että koulutuksen tehtävänä on ohjata 
oppilasta muodostamaan oma yksilöllinen ja kulttuurinen identiteettinsä auttamalla häntä tunnistamaan juurensa ja sijoittumaan siihen kulttuuriympäristöön, jossa hän elää ja saa yksilöllistä kehitystään ja elämän tarpeitaan muovaavia kokemuksia. Sivistys siis kasvaa yksilön ja kansakunnan yhteisestä kokemuksesta. Tätä käsitystään Grundtvig nimitti termillä folkelig. Suomeksi se on käännetty muotoon kansainen, kansasta nouseva sivistys.

Vaatimus opetuksen perustamisesta opiskelijan tarpeisiin ja opettajan sekä oppilaan persoonalliseen vuorovaikutukseen heijastelee yhtäältä Grundtvigin omaksumaa valistusajattelulle ominaista luottamusta ihmisen kykyyn itse määritellä omia tarpeitaan ja toisaalta romanttiselle maailmankuvalle pohjaavaa käsitystä, jonka mukaan yksilön elämänkokemus, hänen henkilökohtainen historiansa, on se perusta, jonka varassa hänen toimintavalmiutensa kehittyvät. Valistuksen oppien mukaisesti Grundtvig taas näki, että autoritäärisyys opetusmenetelmänä tuhoaa opiskelijan luovuuden ja oma-aloitteisuuden, tekee hänestä alamaisen tottelijan, joka oppii vain koulua, ei elämää varten. Tasa-arvoiseen vuorovaikutukseen nojaava opetus sensijaan kasvattaa oppilaan rohkeuteen ja toimeliaisuuteen. Se auttaa häntä kasvamaan kansalaiseksi, joka oppii elämää, ei koulua varten.

Tältä pohjalta Grundtvig arvosteli ankarasti oman aikansa vallitsevaa sivistyskäsitystä ja opetusmenetelmiä. Hänen mukaansa tanskalainen musta latinakoulu oli elämälle vieras, epäkansainen laitos, joka ainoastaan kasvatti yläluokan lapsista vierailla kielillä autoritäärisin menetelmin sääty-yhteiskuntaa ylläpitäviä, yhteisestä kansasta vieraantuneita virkamiehiä. Näin toimiessaan se Grundtvigin mukaan irrotti sivistystyön historiallisista ehdoistaan vapaaksi, muodollisten kelpoisuuksien ja yleisten totuuksien tuottamiseksi.

\section{Grundtvigin ajattelun varhaiset historialliset edellytykset}

Miksi kansainen sivistyskäsitys syntyi Tanskassa ja levisi sieltä Pohjolaan? Miksi se ei syntynyt tai saanut jalansijaa etelämpänä Euroopassa? Selityksen juuret ulottuvat uuden ajan alkuun. Protestanttinen uskonpuhdistus ja sitä Pohjolassa seurannut puhdasoppisuuden kausi käänsivät jumalanpalvelukset kansan kielelle, koska kaikkien kristittyjen pappeus ja saaman keskeinen asema jumalanpalveluksessa olisivat olleet tarpeettomia opinkappaleita, ellei rahvas olisi omakohtaisesti ymmärtänyt niiden sisältöä. Luterilainen oppi siis sisälsi kansansivistyksen vaatimuksen. Lukukinkerit olivat sen näkyvä ilmentymä. Kirkko otti tehtäväkseen kristinuskon sanoman juurruttamisen kansaan katekismuksen kautta. Rukoillessaan joka sunnuntaisissa jumalanpalveluksissa menestystä lailliselle esivallalle luterilainen kirkko otti myös yhteiskunnallisen opettajan roolin. Se pyrki kasvattamaan kruunulle kunnon alamaisia. Valistuneella 1700-luvulla - hyödyn aikakaudella - kirkko edelleen laajensi kansanvalistajan rooliaan. Papit huolehtivat paikallisesta hallinnosta, luennoivat ja saarnasivat hyvästä talonpidosta, uusista viljelymenetelmistä ja jumalalle otollisesta ahkeruudesta. Samalla kirkko alamaisia ankaruudella kasvattaessaan ja opettaessaan tuli myös synnyttäneeksi herätysliikkeet, kansanliikeyhteiskunnan ensimmäiset airuet, jotka osaltaan loivat perustaa kansan omaehtoiselle sivistysliikkeelle.

Kirkon valistustoiminnan ohella toinen tärkeä grundtvigilaisuuden edellytys oli pohjoismaiden yhteiskuntien sosiaalinen rakenne. Feodalistisen yhteiskuntajärjestyksen muovaamaan eteläisempään Eurooppaan verrattuna lievät yhteiskunnalliset säätyerot ja sosiaaliset vastakkaisuudet sekä niiden vastapainona talonpoikaisen vapauden perinne mahdollistivat ajatuksen kansaisesta sivistyksestä.

1800-luvulle tultaessa valistuksen järkiuskon rinnalle oli tullut romanttinen maailmankuva ja siihen kiinteästi kuuluva kansallinen ajattelu. Jos valistuksessa oli kaipuuta yleiseen tietoon, tiedon yleispätevyyteen, romantiikassa korostui historiallisesti sidonnainen tieto. Romantiikalle oli ominaista mytologioiden, perinteiden, oman kulttuurin menneisyyden etsiminen ja korostaminen ihmisen elämän rakennuspuina. Romantiikka kytki näin tiedon historiallisiin ehtoihin. Tähän liittyi kansallisen ajattelun herääminen, joka on osa romantiikan ajan maailmankuvaa. 
Juuri kansallisuusaate sytytti kansanvalistuksen kipinän lopulta liekkiinsä. Sekin sai Pohjoismaihin tullessaan kansaisen sisällön. Yksi kansa ja yksi kieli oli kaikkien Pohjolan maiden kansallisten herättäjien tunnuksena. Tanskan törmäys laajenemishaluisen preussilaisen nationalismin kanssa Schlesvig-Holsteinin alueen rajakiistassa synnytti maahan ensimmäisen kansanopiston 1844. Kansainen sivistys oli voima, jonka avulla puolustautuminen mahtavaa vihollista vastaan olisi mahdollista.

\section{Teollisuuden nousu}

Ennen kuin kansansivistystyö vielä muuttui näistä tiedollisista ja aatteellisista aineksista toiminnaksi, myös yhteiskunnan arkisen toiminnan, työn ja tuotannon, tasolla tuli tapahtua vastaavanlaisia muutoksia. Ne tapahtuvat teollisen kumouksen kautta. Teollistuminen oli kaikkein tehokkain sääty-yhteiskunnan romuttaja. Syntyi vapaasti liikkuva palkkatyöläistö, joka ei enää vuosisataisten perinteiden mukaan asunut samoilla paikoilla ja ollut samoissa tehtävissä, vaan joutui teollisen elämän myötä etsimään elämänsä ehtoja muuttuneessa tilanteessa.

Teollisen yhteiskunnan sosiaalinen liikkuvuus edellytti poliittisella tasolla monien vanhojen rajoitusten purkamista. Tämän vapautumisen aatteelliseksi edustajaksi nousi liberalismi. Liberalismia voidaan ajatella poliittisena ja aatteellisena motivaationa ja perusteluna teollisen maailman todellisuudelle. Näin liberalismi otti korostaakseen yksilön vapaudenaatteita, jotka tänä päivänäkin ymmärrämme klassisen liberalismin lähtökohdaksi.

Kaikki tämä yhdessä johti kehitykseen, joka 1800-luvun Euroopassa, ennen muuta Pohjoismaissa, laajeni nopeasti ja jota on kutsuttu kansalaisyhteiskunnan synnyksi. Enemmän kuin koskaan aiemmin historiassa kansalaiset nousivat yhteiskunnassa tietoisesti merkittävään asemaan. Poliittiset vapaudet, äänioikeuden yleistyminen yms. merkitsivät sitä, että kansoja ei johdeta enää dynastisten perinteiden nojalla ylhäältä alas päin, vaan kansalaiset alkavat keskustella ja olla vuorovaikutuksessa yhteiskunnan yläkerran ja hallitsevien piirien kanssa.

\section{Yhteiskunnalliset edellytykset 1800-luvun Suomessa}

Entä niitä tapahtui Suomessa? 1800-luvun alku merkitsi meillä sisäisen, valtiollisen itsenäisyyden rakentumista.

Varsinainen kansalaisyhteiskunnan synty, joka tekee akuutiksi vapaan sivistystyön tarpeen, kulminoitui 1800-luvun puolivälin jälkeiseen aikaan. "Hyvän keisarin", Aleksanteri II:n kaudella meillä toteutui joukko yhteiskunnallisia uudistuksia, jotka merkitsivät radikaalisti uudenlaista yhteiskunnallista ja kulttuurista tilannetta verrattuna vuosisadan alkupuoleen. Valtiopäivätoiminta käynnistyi. Se oli vielä säätypohjaista, mutta yhtä kaikki se merkitsi sitä, että autonomisen Suomen asioita alettiin käsitellä meidän omassa valtiopäivälaitoksessa. Kunnallinen itsehallinto erotettiin kirkon hoidosta.

Näiden uudistusten vaikutuksesta, erityisesti kunnallishallintoa varten, nousi hetkessä kansan syvistä riveistä sankka joukko isäntiä, jotka alkoivat hoitaa oman lähiyhteisönsä asioita ja vaikuttaa koko kansakunnan kehitykseen. Keskeinen kunnallishallinnon tehtävähän oli muun muassa kansakoululaitoksen järjestäminen, josta tehtiin päätös säätyvaltiopäivillä.

Poliittisten uudistusten taustalla ja rinnalla tapahtui taloudellis-sosiaalinen murros. Elinkeinovapauden toteuttaminen 1850-luvulta 1870-luvulle merkitsi teollistumisen läpimurtoa. Sitä seurannut väestön sosiaalisen ja ammatillisen rakenteen murros loi vaativan kansansivistyksellisen tehtävän antaen vauhtia koululaitoksen kehittämiselle. Poliittiset vapausaatteet tulivat asteittain ja saivat myöhemmin omat poliittiset liikkeensä ja toteuttajansa. 
Näin kuvatut yhteiskunnan muutokset kypsyttivät myös sivistyksellisten ja koulutuksellisten tarpeiden esiinnousua. Kansallinen herätys, joka lähti liikkeelle 1800-luvun alussa ja jonka tietynlainen huippukausi oli lähestyttäessä vuosisadan puoliväliä, korosti nimenomaan valistuksen merkitystä. Snellmanin ajatukset nousivat saksalaisesta romanttisesta filosofiasta, joka hänellä ja Grundtvigilla oli yhteinen. Kansallinen herätys korosti näin sivistystä ja tietoa itsenäisen kulttuurin ja ihmisen elämisen perusehtona. "Kansa on sivistettävä", oli iskulause, joka periytyi Snellmanista ylioppilasliikkeeseen.

\section{Kansansivistysaatteen tulo Suomeen}

Kirjaan seuraavaksi varhaisimpia kansansivistysliikkeitä, jotka ottivat kypsyneen yhteiskunnallisen tilanteen haltuunsa ja alkoivat toteuttaa käytännössä snellmanilaista sivistysohjelmaa

Fennomania poliittisena liikkeenä ei mieltänyt itseään vain puolueeksi, vaan se katsoi muodostavansa suomalaisuusliikkeen ytimen ja edustavansa koko Suomen kansaa ja sen kulttuuritraditiota. Sillä oli poliittisen periaateohjelmansa runkona sivistyspoliittinen ohjelma ja se osallistui aktiivisesti myös sivistystyön organisointiin.

Ylioppilasliike oli kiinteä osa fennomanian sivistyspoliittista toimintaa ja osakunnat nousivatkin keskeisiksi voimatekijöiksi kansanvalistuksen käynnistämisessä. Ylioppilaiden kiinteä kosketus kansallisten tieteiden harjoittamiseen antoi heille myös erityisen tehtävän kansanvalistuksen perusteiden muovaamisessa.

Työväenliike saapui Suomeen 1880-luvulla. Sen ensimmäiset toimintamuodot kytkeytyivät nekin läheisesti valistamisen ajatukseen. Ensimmäiset ammattiosastot kiinnittivät suurta huomiota työväestön yhteiskunnallisen tietoisuuden herättämiseen erilaisin valistustoimin. Samoin poliittisen työväenliikkeen varhaisin, wrightiläisen liikkeen nimellä tunnettu vaihe, perusti keskeisesti toimintansa valistuksen varaan. Se oli luonteeltaan ylhäältä alas suuntautuvaa patriarkkaalista toimintaa, joka velvoitti ylempiin sosiaaliryhmiin kuuluvia kantamaan moraalista vastuuta työväestöstä. Päämääränä oli radikaalin sosialismin ja sen muodostaman kumousuhkan torjuminen työväestöä sivistämällä ja yhteiskunnallisia vastakohtaisuuksia korostavia epäkohtia konsensuksen hengessä korjaamalla.

Kansalaiset reagoivat yhteiskunnallisen ilmaston vapautumiseen spontaanisti. Raittiusliike syntyy torjumaan alkoholin eritoten teollisuustyöväestön piirissä luomia epäkohtia. Maamiesseurat ja naisosastot ryhtyvät edistämään maatalouselinkeinon uudistumista ja kilpailukykyä muiden elinkeinojen kanssa. Nuorisoseuraliike käynnistyi ja otti erityiseksi tehtäväkseen maaseudun nuorison sivistämisen. Monenlaiset kulttuuriset ja sivistykselliset riennot syntyvät nuorisoseuraliikkeen toiminnan kautta. Patriarkkaalinen yhteiskuntakäsitys sai haastajan, kun naisliike, vaikka meillä varsin maltillinen, heräsi sukupuolten välisen tasa-arvon edistämiseen niin perheen piirissä, kuin ammatillisissa ja koulutuksellisissakin kysymyksissä.

\section{Vapaa sivistystyö käynnistyy Suomessa}

Se, mikä oli tapahtunut Tanskassa, toistui puoli vuosisataa myöhemmin ensimmäisen sortokauden Suomessa. Kansallismielisten ylioppilaiden ja valistuneiden talonpoikien yhteinen vastaus Venäjän uhkaan oli kansalaisen sivistyksen voima.

Keskustelu kansansivistystoiminnan käynnistymisestä oli käynnistynyt Suomessa 1860-luvulla. Sen tuloksena ensimmäinen nimenomaan kansanvalistusjärjestöksi luotu yhteisö oli fennomaanien 1874 perustama Kansanvalistusseura (KVS). Professori Kosti Huuhka on luonnehtinut seuran toiminnan alkua kirjakerhotoiminnaksi. Kansantajuisten, mutta silti syvällisten ja täysipainoisten tieteellisten ja kaunokirjallisten teosten saattaminen laajojen kansalaispiirien ulottuville oli keskeinen tavoite. Toiminnan taustalla vaikuttavat vuodesta 1831 toiminut Suomalaisen Kirjallisuuden Seura ja jo alkuun päässyt yleinen 
kirjastotoiminta. Merkittävin KVS:n omista tuotteista oli 1950-luvulle saakka vuosittain julkaistu Kansanvalistusseuran kalenteri, aikansa Mitä-Missä-Milloin -teos.

Kansanvalistusseura sysäsi sitten liikkeelle muitakin sivistystyön muotoja. Käynnistettiin eri paikkakunnilla kansanopistotoiminnaksi kutsuttua luentotoimintaa, laadittiin internaattimuotoista kansanopistotyötä varten malliohjesääntö ja järjestettiin suuria laulu- ja musiikkijuhlia, kansallisen kulttuurin näyteikkunoiksi.

Kansanopistoliikkeen rooli yhteiskunnallisena uudistusliikkeenä näkyy ensimmäisen opiston perustamisessa. Tämän 1889 Kangasalle perustetun opiston perustaja oli Tanskassa opistotyöhön tutustunut Sofia Hagman ja opisto oli tarkoitettu naisille. Vuosisadan vaihteeseen tultaessa maahan oli perustettu kaikkiaan 22 opistoa, ja perustaminen jatkui seuraavina vuosina yhtä kiivaana, mikä hyvin kuvaa vallinnutta innostusta. Autonomiakauden päättyessä opistoja oli jo nelisenkymmentä. Saavutus on jo pelkästään taloudelliselta kannalta huomattava kansalaisaktiivisuuden osoitus, sillä alunpitäen internaateiksi perustetut opistot vaativat huomattavan määrän varoja, eikä valtio tuolloin tullut apuun.

Työväenopistotoiminta käynnistyi kymmenen vuotta kansanopistotyön alkamista myöhemmin, ja taustana on nähtävä Kansanvalistusseuran aloittamat kurssit. Ensimmäinen työväenopisto perustettiin Tampereella 1899. Sen jälkeen uusien opistojen perustaminen oli vilkasta. Ne syntyivät nimensä mukaisesti ennen muuta teollistuvan Suomen asutuskeskuksiin työväestön tarpeisiin. Työnjako agraarisen Suomen palvelukseen asettuneiden kansanopistojen kanssa oli selvä. Myös työväenopistojen perustamisessa yksityisen kansalaistoiminnan panos oli ratkaiseva.

Nuorimpana vapaan sivistystyön muotona syntyivät sivistysjärjestöt. Työväen Sivistysliitto (TSL) on niistä vanhin. Se perustettiin 1917. Tämä työmuoto on alunpitäen ollut kansalaisjärjestöjen sivistystarpeiden palveluksessa. Kansanopistojen tavoin niiden toiminta on osa kansanliikkeiden arvopohjalta nousevaa sivistystyötä.

\section{Kehitys nykypäivään}

Vapaan sivistystyön historia Suomessa on jaettavissa useampaan sisäisesti yhtenäiseen kehitysvaiheiseen. Nämä jaksot välittävät kuvan sivistystyön ja yleisen yhteiskunnallisen kehityksen keskinäisestä suhteesta. Tyydyn tässä kolmijakoon, joka on väljä ja tarkempaa analyysiä varten edelleen jaoteltavissa, mutta samalla kuitenkin antaa tämän artikkelin tavoitteiden kannalta riittävän selkeän kuvan.

Ensimmäisen kehitysvaiheen muodostaa ajanjakso kansallisen herätyksen varhaisvaiheesta suunnilleen itsenäisen Suomen syntyyn. Tällä ajanjaksolla on vallitsevana grundtvigilais-snellmanilainen kansallisromanttinen henki ja ajattelutapa, joka voimakkaasti korosti kielen ja kulttuurin merkitystä yksilön ja kansakunnan koossapitävänä voimana. Autonomiakaudella toimineiden kansanopistojen kasvatustyön tavoitteena oli käytännöllisten isännän ja emännän taitojen edistäminen, mutta sen tuli tapahtua niin, että samalla kasvatettiin suomalaisuudestaan tietoisia emäntiä tai isäntiä. Näin asennoituva sivistystyö joutui väistämättä ristiriitaan venäläistämistoimia toteuttavan esivallan kanssa. Se sai tahtomattaankin ylleen yhteiskunnallisesti radikaalin toiminnan leimaa. Osoituksena tästä ovat opistojen perustamistoimien estämiset ja opistoihin kohdistunut viranomaisten tarkastustoiminta, jonka tarkoituksena oli erityisesti yhteiskuntaopin ja Suomen historian opetuksen valvonta. Moni kansanopisto aloitti toimintansa osin tästä syystä emäntä- ja isäntäkouluna. Näin niillä oli myös mahdollisuus pienen valtionavun saamiseen, mikä separatismista epäillylle kansanopistolle ei ollut lainkaan mahdollista.

Ensimmäinen kehityskausi oli siis herättämistä. Se oli aktiivisen, itsetietoisen ja arkisissa askareissaan taitavan kansalaisen kasvattamista. 
Toisen kehitysperiodin muodostaa ajanjakso itsenäistymisestä toisen maailmansodan päättymiseen. Jos ensimmäistä kautta luonnehti tietynlainen yhteiskunnallisen emansipaation ajatus, jopa radikalismikin, niin toisessa vaiheessa tämä puoli vaimentuu ja pannaan aisoihin. Muutos on historian perspektiivistä hyvin ymmärrettävä. Autonomiakaudella tavoitteena ollut suomalaisen kulttuurin itsenäisyys koettiin valtiollisen itsenäistymisen kautta saavutetuksi. Saavutus oli ollut tuskallinen ja nyt se oli turvattava.

Kansansivistystyö ottaakin tehtäväkseen 1920- ja -30 luvuilla saavutetun itsenäisyyden turvaamisen. Tämä näyttäisi merkinneen myös uutta suhtautumista siihen, mitä kansallisella kulttuurilla ymmärrettiin. Aiemman vaiheen kielikulttuurikeskeisyys muuttuu valtiokeskeisyydeksi, identiteettiään luovien kansalaisten kasvatus vaihtuu valtiokansalaisten kasvattamiseen ja vapaus järjestyksen noudattamiseen. Kansanopistoliikkeen sisällä muutos näkyy siinä, että sotien välisenä aikana perustettavat uudet opistot ovat miltei poikkeuksetta kristillisiä opistoja. Niiden kristillis-isänmaallinen maailmankatsomus sopeutui hyvin aikakauden henkeen. Uusia grundtvigilaisia opistoja sen sijaan perustettiin vain kaksi. Kansallisidealistisen ajattelun aika oli ohi.

Itsenäistymisen ja sisällissodan tuskallisten tapahtumien seuraukset tulevat näkyviin myös siten, että kansansivistystyö menettää kaikkia kansalaispiirejä kokoamaan pyrkivän yhtenäisyysihanteensa. Sen halkaisee luokkayhteiskunnan sosiaalista ryhmittymistä noudattava jako, joka kulkee karkeasti kansanopistojen ja työväenopistojen välissä. Poikkeukseton se ei ole, mutta kuitenkin perustilannetta vallitseva. Maaseudulla toimivat kansanopistot imevät itseensä valkoisen Suomen poliittisen ja yhteiskunnallisen arvomaailman (poikkeuksena 1924 perustettu Työväen Akatemia) ja työväenopistot vuorostaan edustavat kaupunkityöväestön, punaisen Suomen arvomaailmaa.

Kolmas, kehitysvaihe käsittää sotien jälkeisen ajan. Muutos toisen vaiheen asetelmista uuteen tilanteeseen tapahtui kuitenkin asteittain, ei jyrkästi. Sotien välisen kauden arvomaailma vallitsi vielä pääosin sivistysliikkeen toimintaa tultaessa 1950-luvulle, vaikka kypsyvä muutos olikin jo aavistettavissa. Jos ensimmäisen tasavallan sivistystyötä voisi yleistäen kuvata kansallisvaltion ideologisen rakentamisen kaudeksi, oli nyt tultu kaupungistuvan, tehtävän mukaisesti eriytyneen yhteiskunnan aikaan. Tämä merkitsi kansanopistojen osalta asteittaista luopumista laaja-alaisista kansanopistokursseista ja siirtymistä profiloitujen opintolinjojen ja erikoiskurssien tarjontaan, yleisistä kasvatustavoitteista ammatillisesti tai muutoin eriytyneisiin koulutustehtäviin. Tähän pakottivat yhteiskunnan rakennemuutos ja koulutusjärjestelmän laajentuminen. Tyypillisiä uusia kansanopistoja olivat järjestöpohjaiset, ay-liikkeen ja puolueiden perustamat opistot.

Työväenopistojen osalta muutos näkyy myös nimessä. Uudet opistot ovat kansalaisopistoja ja moni vanha työväenopisto harkitsee nimensä modernisointia. Sivistysjärjestölle kenttä avartuu, mukaan tulee uudentyyppisiä puolueettomia järjestöjä. Kokonaisuudessaan vapaa sivistystyö astuu järjestö- ja organisaatio-Suomen palvelukseen. Aiemmat ideologiset vastakkainasettelut vaimenevat ja sijaan tulee vuoropuhelu. Perustellusti voidaan myös todeta aatteellisuuden vaimentuneen pragmaattisen koulutusajattelun hyväksi. Se on ollut ajan henki.

\section{Historian anti tulevalle}

Elämme nyt 1990-luvun Suomessa rajun yhteiskunnallisen murroksen aikaa. Se koettelee yhtä hyvin taloudellisia, poliittisia ja sosiaalisia rakenteita kuin yhteiskuntaa koskevia asenteitammekin, myös koulutukseen liittyviä. Emme voi varmuudella ennakoida edes aivan lähiaikojen kehitystä, laskemattomia tekijöitä on liian paljon. Yksi on kuitenkin varmaa. Suomalaisen yhteiskunnan kansainvälistymisen vauhti on kasvanut rajusti ja pysyvästi. Todennäköisesti myös monet hyvinvointi- ja täystyöllisyyden yhteiskuntaa koskevat odotuksemme ovat tulleet mahdottomiksi. Yhdessä nämä muutokset synnyttävät mielissämme suurta epävarmuutta ja epävarmuus vuorostaan tekee välttämättömäksi arvokysymysten pohtimisen, koska vakiintuneet arvot järkkyvät ja näyttävät menettävän merkityksensä. 
Euroopan tasolla on jo selvästi nähtävissä, miten taloudellinen epävarmuus ja meneillään oleva perinteiset kansalliset ja kulttuuriset rajat ylittävä integraatiokehitys ovat nostaneet esiin pelkoja, jotka ilmenevät etnisinä ongelmina, kansalliskiihkona ja rasismina. Ne kertovat epävarmuuden nostamasta arvokriisistä. Nämä ongelmat ovat myös meidän edessämme.

Edellä tehty retki vapaan sivistystyön historiaan on osoittanut, että vapaa sivistystyö on halki olemassaolonsa käynyt vuoropuhelua kunkin aikakauden henkisten virtausten kanssa. Sen toiminnat ovat laajentuneet ja muuttuneet ajan tarpeiden mukaan ja ne ovat aina palvelleet kunkin aikakauden kansalaisyhteiskuntaa, sen tarpeita. Ellei näin olisi tapahtunut, vapaa sivistystyö olisi kuollut. Sen tarjoamat palvelut ovat aina olleet ihmisten vapaasti otettavissa tai jätettävissä.

Vapaan sivistystyön tulevaisuuden kannalta tämä merkitsee sitä, että sen alkuperäisen idean mukainen historian ja kulttuurin merkitystä sivistystyölle korostava tietokäsitys ja siihen pohjaava pedagogiikka ovat yhä päteviä työvälineitä. Sivistystyön tehtävä on yhäkin auttaa ihmisiä jäsentämään oma asemansa sen kulttuurin piirissä, jossa he elävät.

Koulutuksen tehtäväksi ei näytäkään riittävän puhtaan universaalin tiedon jakaminen ja siihen perustuvien ennalta määriteltyjen kelpoisuuksien tuottaminen, kuten viime vuosina usein on otaksuttu. Historian kehitys ei näytä tottelevan parhaintakaan ennustetta, vaan meidän on aina palattava kysymään myös sitä, miksi kaikki ei mennytkään kuten meille luvattiin. Vain omaehtoisesti toimiva ja itsenäisesti omia tavoitteitaan etsivä oppimishaluinen ihminen kykenee tähän. Siksi vapaata sivistystyötä tarvitaan ja siksi sen tehtävänä on tulevaisuudessakin antaa ihmisille mahdollisuus itseohjautuvaan oppimiseen. Se merkitsee yksilön ja kansalaisen omien valintojen kunnioittamista, luottamusta hänen omiin kykyihinsä. Se on osa demokraattisen kansalaisyhteiskunnan perusrakennetta. 